\title{
Industrial heritage and conservation planning, changing governance practices, examples from Europe
}

\section{Loes Veldpaus and Remi Wacogne}

\section{Introduction}

In most European countries, there exists a regulatory system for conservation planning and heritage management, consisting of a combination of subnational, national and supranational guidelines, policies, codes and laws. Whether the policies and laws that apply are very rigid, more indicative or mostly absent, they have an impact on the historic built environment, historic preservation and the perception of heritage. They not only set limits of acceptable change but also effectively decide what is considered heritage: officially and, more broadly, perceptually. However, as heritage is a cultural practice, practitioners play a significant role in defining and developing its workings and doings. This also means that practices can significantly vary, even within the same legal framework. Heritage management practices are constantly evolving, and ideas around heritage are shifting; notably affected by changes in urban governance, in addition to the pressure (or lack thereof) of urban development.

In this chapter, we will discuss some of the results of the project 'The impact of urban planning and governance reform on the historic built environment and intangible cultural heritage' (PICH). In this project, our aim was to examine the complex structure of policies, processes, practices and people that is driving decision-making for the historic environment in the Netherlands, England, Italy and Norway. The research consisted of 12 in-depth case studies, 
using policy analysis, documentary research, expert interviews and street interviews with visitors and residents. We looked at three settings: historic urban cores, former industrial areas and the urban landscape across these four countries (Nadin et al. 2018). By analysing a variety of localities across Europe, we sought to further the understanding of how changes to urban governance are influencing heritage management across Europe. By taking a governance perspective, the aim is to draw attention to the limitations of the formal organization of government and its planning policies and heritage protection mechanisms.

Historically, urban heritage management practices intended essentially to preserve the fabric of the past for future generations, focusing on the tangible and aesthetic dimensions of heritage. This was challenged by the concept of Authorized Heritage Discourse (AHD) developed by Smith $(2006,11)$, who questioned why 'heritage' often seems limited to “"old”, grand, monumental and aesthetically pleasing sites, buildings, places and artefacts'. The past decades have seen a push for broadening the heritage concept, and a move from such a restricted $\mathrm{AHD}$, with its inherent materiality and assumed intrinsic value. Heritage is now more commonly understood as a process mobilizing socially constructed values, as well as a distinctively performative one in relation to places (Hall 1999; Smith 2006, chapter 6; Harrison 2012, chapter 5). It is seen as a way of (re)enacting and mobilizing some past(s) in the present (Hart 2011; Meskell 2015). As such, heritage can be seen as a process of instrumentalizing place, using the past as a social, political or economic resource (Graham et al. 2000) as well as a process of constructing (un)belongingness, and thus a constructed 'other' who can never fully belong. Work that looks at what heritage 'does' rather than what it 'is' is becoming much more common (Crooke and Maguire 2018; Smith et al. 2018). A lot of this work is being done within the museum sector, and there is a need for further development of this thinking in urban contexts (Kisić 2017; Tolia-Kelly et al. 2017; Sinclair-Chapman 2018).

\section{Changes to heritage governance}

By looking at the influence of global forces such as the economic crisis, we aimed to understand how structural changes are shared (or not) and dealt with within different planning and heritage systems. In Italy, the Netherlands and England, the 2008 crisis brought austerity measures; in all four countries, so including Norway, it led to changing values and attitudes toward priorities for development (and a growth agenda) and to a much-reduced capacity for local governments to intervene directly in urban development and conservation. 
This reinforced and accelerated neoliberal thinking in urban governance, leading to more market-oriented mechanisms for delivering services and projects, and a loosening of public regulation (Pendlebury et al. 2019). It also led to an increased emphasis upon the economic value of heritage assets and narratives, as heritage has become an even more explicit means to instrumentalize place (Wacogne 2018; Veldpaus and Pendlebury 2019). Concurrently, there has been a push for a more liberal approach to heritage, aiming not just at increasing the range of what can become heritage, but also at stimulating participatory practices and a push for increased local involvement.

In the cases we looked at, both these neoliberal and liberal trends led to varying degrees of visible change in urban heritage governance, depending on the national political, economic and cultural contexts, as well as on the type of heritage and its location. Much of the change we observed was prompted by austerity measures leading to less public investment, and thus to a need for commercial or civil society-led projects. Local heritage and planning authorities act more and more as facilitators, guiding and shaping policies and activities of other key actors rather than directly implementing and financing change. As such, the form and level of influence that public bodies and public investment have in the conservation of the historic environment is changing critically. While this may undermine collective efforts to conserve, it may also bring in new civil and private actors and inward investment into the heritage sector, and as such it is a platform for new actors and thus for new voices.

Our aim was to look at the governance of the historic environment. While the regulatory system has not changed significantly since the 2008 crisis in any of the countries we looked at, conservation practices, and particularly the roles and responsibilities of the actors involved, did change quite considerably in some of our cases. The two themes we focus on in this chapter are firstly, the further normalization of partnership working - in particular, the changing roles and responsibilities within those partnerships - and secondly, the increased focus on pragmatic and highly selective heritage practices, or on what could be termed 'useful' heritage.

\section{Partnerships}

Partnership working in urban governance or heritage management processes isn't new (Davoudi 1995; Pendlebury 2002), but it has intensified and changed in nature over the last decade. Originally, partnerships were often set up and led by the public sector according to the 'New Public Management' approach, 
with the aim of fostering a more competitive, accountable, efficient and entrepreneurial public sector (Cook 2009). In this project, we saw that these urban governance arrangements are moving towards what Rex (2018) calls 'other-than-public' forms of management of urban processes, places or assets. She defines these 'other-than-public' forms of management as those that are not public sector led, but still use a language of affinity with public sector ethics, ideals and ambitions; for example, non-governmental organizations (NGOs) (e.g. a trust or charity) or some sort of cooperative or community and/or not-for-profit company. So, while local authorities still take part in such processes, and also still have to deal with planning and heritage permit applications, they are no longer the initiating or leading partner, even when it comes to area development (Veldpaus and Pendlebury 2019).

Whether it is following development logics, austerity, small-state ideology or a push for participatory approaches, or a mix of all the above, we see a redistribution of roles and responsibilities in partnerships involved in (urban) heritage governance. We found that other-than-public actors are taking, and are expected or encouraged to take, larger responsibilities, including lead roles, in urban heritage governance. Subsequently, the (local) government's role is in some cases being reduced to that of a 'critical facilitator'. The outcomes of conservation interventions then come to depend more and more on both the capacity and the aims of those other-than-public actors, and the new governance arrangements influence the uses, concepts and narratives of heritage. This was stronger in the English context than it was in the other countries, but to some extent these results of shifting roles and responsibilities were visible in all cases. These other-than-public actors, while using the 'public' discourse, usually have little legal or formal responsibility toward the wider public. Therefore, it is up to them how inclusive and responsive they are in their approaches and ideas. They also seek more flexibility, as their potential in terms of networks, resources, knowledge and experience affects their projects' outcomes. Lack of democratic accountability, long-term sustainability and responsibility are also potential issues in such processes.

To explain in more detail how these partnership workings influence heritage, we now turn to the industrial heritage 'typology', one of the three themes in the $\mathrm{PICH}$ project, along with historic urban cores and urban landscapes (Nadin et al. 2018). These areas are a commonplace feature of most cities as changing demands of industry and economic restructuring have made many industrial sites redundant. Their location - close to city centres - in combination with relatively low land values makes them attractive for transformation. The four industrial heritage cases represent different industrial periods. In Italy we looked at the Goccia area in Bovisa, Milan, a former complex of gasworks and 
chemical plants; in Norway and the Netherlands, the case studies were former shipyards, respectively Nedre Elvehavn (TVM) in Trondheim and Rotterdam Droogdok Maatschappij (RDM); and in the UK (more specifically England) we focused on Ouseburn Valley, Newcastle-upon-Tyne, which was at first the location of pottery industries in the seventeenth century, but now consists of a mix of small-scale - some still active - industries. In Milan and Rotterdam, Higher Education Institutes (HEIs) were the main new users and developers, while in Trondheim the new use for the area, promoted through its redevelopment, was leisure. In this case, Nedre Elvehavn, a public-private partnership, was initially set up, but public austerity following the 1980s crisis rendered the project inactive for a decade and the municipality had to sell its stake in the project to private companies. They then developed the site privately. In Ouseburn, the Ouseburn Partnership (18 partners), led by the Ouseburn Trust (a local NGO), initiated the redevelopment of the area by successfully bidding for $£ 2.5$ million from central state funding (the 'Single Regeneration Budget').

The cases within the (post-) industrial theme of the research project are especially interesting to look at here because the approaches used were rather experimental and less essentially heritage-centred; more so than in historic urban cores and urban landscapes. Although heritage plays a role, in all four industrial case studies the partnerships were set up for the management and redevelopment of the area. The processes were characterized by a certain degree of flexibility toward heritage and, although we did not investigate the reasons behind this further, it was clearly considered more acceptable to make material changes to industrial heritage, in comparison to the heritage considered within the historic urban core. This is partly because most countries have little direct policy on what industrial heritage is (thus differentiating it from heritage in general) and how it should be protected, and partly due to a lack of funding for what are often vast derelict areas to develop, and (as a result) pressures to develop for commercial uses.

Ownership structures are related to former use, and influence how both the areas and the partnerships develop. With only one or a few larger landowners and a fairly singular industrial use, there tends to be a more sudden shift, for example after bankruptcy, from active to inactive, as well as the other way around. Also, the need for decontamination and other sometimes very challenging conditions (retaining walls, very robust or very fragile ruinous buildings) have impacted on partnership formation and transformation processes, slowing them down or bringing them to a halt altogether, sometimes for several years (they are still going on in the Italian case, more than two decades after the last plant shut down). The role of time, both in terms of the processes at work and the more 'recent' nature of most of the industrial heritage sites we 
looked at, seems an important factor in the more flexible approach to these sites (Carughi and Visone 2017).

Experiment, as we encountered it, relates to this more flexible attitude, as well as the need to negotiate between developers' interests and conservation requirements. The other-than-public stakeholders are often new to heritage and have had to learn rapidly to operate in this specialized field. They are, however, not new to area development and come with new ideas and approaches, as they bring their own knowledge and expertise to the governance arrangements of heritage area development practices. For instance, they utilized or developed their own governance and area-management mechanisms (e.g. port companies, campus development), largely unknown in the heritage field. The approaches we observed included all sorts of branding and marketing tools, used to create a favourable climate for specific groups of users (i.e. artists, education workers, start-ups) that 'fit' the brand, for example by providing low-rent and longer-lease options, rent and facilities 'package deals' or shared facilities. When deemed important to such groups, there was also an emphasis on the opportunity offered to new users to have a say in future development, for example by collaborative planning, the (co-)organization of place 'branding' activities and events (cultural events, pop-ups, markets, festivals, expositions) or by developing guidance on how to deal with the historic buildings.

For those new actors, however, using (former) industrial areas is not necessarily about heritage. It is just as much, or more, about the type of space, the freedom and flexibility in reuse granted to industrial heritage, the location in relation to the city centre, the geography, or the identity it gives, as being alternative, 'quirky' or a 'maker space'. This we saw in particular in Rotterdam and Milan, where HEIs were redeveloping former industrial spaces through projects that were very much about using heritage to foster identity, building on an image of the area and of its industrial 'glory' - an area of creators, inventors, makers, innovators - but were also very practical about the large spaces the buildings offer. In both cases, at least initially, an HEI approached the areas as 'industrial' heritage - in the broad sense of the word - and undertook an adaptive reuse project, but without having to adhere to the legal framework around heritage. In Italy, high costs of land decontamination and the restrictive regulations associated with this process played a decisive role in downgrading conservation as a priority. In Rotterdam, the partnership negotiated a guided (by the Netherlands Heritage Agency) process of redevelopment, while agreeing that listing would only happen after this process had finished. 
As partnerships were generally set up to negotiate planning and generate funding for future development, they always had to involve or engage with local authorities to some extent. Financing often came from the market, or through specific sectoral public funding (central or regional state, subsidies, area-regeneration schemes, national project investments or loans, European funding). In more recent times, community funding (e.g. crowdsourcing, crowdfunding, community shares) was added into the mix. In particular, national and European Union (EU) sectoral funding or area-regeneration funds tended to offer consistent incentives to develop certain areas in particular ways, as they are generally associated with a specific focus or guidance in terms of how the money can be spent. Obtaining almost all of these funds has become highly competitive and it was evident how those successful in winning funding in this way had benefitted from having strong networks, a (national) lobby and the presence of a pre-existing delivery framework and consortium.

The level (or lack of) of restriction characterizing the respective heritage management systems conditioned the partnership negotiations. In the Dutch and Norwegian cases, heritage was used as a carrot or stick. In the Netherlands, negotiations between private and public actors were resolved through the involved buildings only after heritage-sensitive development, while in Norway, developers were allowed to develop the area for profit only if they would also fund heritage conservation. In the Italian and English cases, partnerships were instead driven - or opposed - by a group of users with a vested interest in the area, which they passionately cared for (England), facilitated by the local governmental planning frameworks. In the Newcastle case, this group, the Ouseburn Trust, which was established in the 1990s to oppose large-scale developments in the valley, later came to lead the partnership to regenerate the area. In Bovisa, Milan, a group of citizens have recently opposed the partnership plans for the redevelopment of the Goccia area, calling for a more environmentally sustainable option and greater public consent.

\section{Usefulness}

We also identified an increased focus on pragmatic and highly selective heritage practices, in other words on 'useful' heritage. To gain and retain legitimacy in a planning process with a growth agenda, one has to follow its logic. Heritage conservation processes thus can't be seen to block or even to be neutral towards economic development; they have to facilitate and stimulate it. Heritage has to be 'useful'. 'Useful' often refers to bringing buildings back into use, but also to making a positive impact in terms of well-being, tourism 
or land value, for instance. Likewise, the stories told and histories mobilized become means of place branding, tourism development or investments. This is not to say that using heritage never happened before, nor that it is inherently a bad thing, but rather that it shows how heritage management is becoming more and more strategic.

The strategic location and the trendiness of post-industrial areas make them attractive for development. Such development schemes generally aim to benefit from a certain 'industrial character' while only loosely engaging with, or conforming to it - or even, in some cases, adversely impacting this character. In all cases, we saw the industrial heritage being used as an attractive setting for twenty-first-century development, especially for certain industries and businesses (e.g. creative, digital, crafts, manufacturing, cafés, bars, restaurants). The use of heritage narratives to create favourable conditions for specific groups of users, such as students, artists and start-ups, or restaurants, cafés and 'unique' or 'quirky' shops, has been observed in all cases. In fact, all the new strategies we identified have been at least partly about branding: getting the right people to that place, making spaces more attractive to a particular audience. This was not unexpected given the push for more market-driven approaches and finance mechanisms and market-led partnerships, as discussed above. Competition provides a general push for branding, putting oneself on the map - and, while drawing upon place identity, tends to generate forms of gentrification and commodification. These are consequences of the process of using - or instrumentalizing - heritage, which are regularly de-problematized or even celebrated. These processes are not necessarily new, but they have deepened and become considered unavoidable or even necessary.

In terms of conservation, links to the industrial past are mostly made in the reuse of parts of buildings and leftover elements (e.g. cranes, machinery) and thus according to a focus on aesthetics and materiality (details, particular materials and colours). Industrial aesthetics are used as an element for 'creative industries' branding; as a reference to a more intangible heritage, such as engineering, manufacturing and innovation. New developments not only use these stories, but also portray current projects as seemingly frictionless continuations of a glorious industrial past; much less attention is paid to, for example, the trauma of lost industries and jobs, hazards and contamination. Such projects rarely address questions of belonging, or if they do, they ignore less positive heritage narratives. The aim is to use heritage sites in a way that makes them attractive and investment-worthy rather than to represent an inclusive story of their history. In fact, in the cases observed, little interpretation of their heritage was offered; the remnants of the past were assumed to be largely self-explanatory and self-evident. 
Argued from a heritage point of view, this means there is a highly selective practice going on, which is mobilizing only the 'useful' stories and assets. Furthermore, the identification of what is 'useful' is now decided or at least negotiated by the main other-than-public actor involved. Of course, such processes are still mediated by regulatory systems, common practices and funding bodies, and - hopefully - by some participatory process. However, in such a context we would argue that it is increasingly difficult to challenge meanings, or to stimulate a multiplicity of them. This leads to a further closing down of the capacity of heritage to be a space for debate and a platform for multiple voices and belongings. As such, we would say, academics as well as local actors could question more what heritage does, and how and for whom it is being (made) useful. What are the alternative or complementary stories not being told; who is excluded? What of the histories of manual labour, shipbuilding, diseases and casualties, or squatting and illegal use?

\section{What future do we imagine, and on which pasts is it built?}

By analysing a variety of localities, we saw how both liberal and neoliberal tendencies are changing urban governance and subsequently heritage management across Europe. The wider governance arrangements revealed further ongoing shifts from public to private, from government to governance, and increasingly important roles for other-than-public actors in partnerships. As discussed above, the changes to partnership working seem to lead to a situation in which the 'use of heritage' turns into the 'usefulness of heritage'.

Heritage has been and will likely always be used for different aims, be it to develop and/or affirm national or local identities or more blatantly as an economic commodity. It will probably also be contested as well as appropriated by 'other' actors, whose interest in heritage might be neither political nor economic. The common focus on the usefulness of heritage emphasized here generally corresponds to the neglect of, or rather to a convenient dismissal of, less 'useful' histories. Little or no space is dedicated to what is often referred to as 'other' stories, such as those of the working class, women, people of colour or LGBTQ, unless there is some - usually financial or ideological - incentive to do otherwise. In other words, investment in those stories the hegemonic group doesn't consider 'theirs' is only made when they serve other aims or ideas of the key actors involved, such as diversity or funding. Once again, the question of which pasts are at work in heritage practices is critical. In this context, it doesn't help that roles and responsibilities within governance arrangements 
are changing - often forcefully and rapidly - and that those changes are not necessarily supported by resources, knowledge and experience.

Industrial and urban heritage in general raises this last question in quite distinctive terms. Indeed, compared for instance to museums, urban spaces are daily used by a diverse audience that is not necessarily aware of their history, although they will experience a version of it. At the same time, even considering former industrial areas and buildings as extreme examples, the interpretation and conservation of urban heritage are still very much in the hands of a limited number of actors, be they public or private. Local communities above all, but also other types of users, should be part of conservation planning processes. In some of the cases observed they are indeed already taking significant - and sometimes unexpected - roles. However, as in more grassroots-driven processes, wider awareness, democratic accountability and an (overt) focus on particular groups and thus histories are also issues to be considered. Heritage is a means to an end, but what end? What future do we imagine, and how and why do we mobilize the past for this? What does heritage do, and is it what we intended it to do? We would argue that those working in and on heritage will need to ask these questions more frequently.

\section{References}

Carughi, U. and M. Visone (eds) (2017), Time Frames: Conservation Policies for Twentieth-Century Architectural Heritage, 1st edn, London and New York: Routledge.

Cook, I.R. (2009), 'Private sector involvement in urban governance: The case of business improvement districts and town centre management partnerships in England', Geoforum, 40 (5), 930-40.

Crooke, E. and T. Maguire (2018), Heritage after Conflict: Northern Ireland, London and New York: Routledge.

Davoudi, S. (1995), 'City challenge: the three-way partnership', Planning Practice and Research, 10 (3-4), 333-44.

Graham, B., G. Ashworth and J. Tunbridge (2000), A Geography of Heritage: Power, Culture, and Economy, London and New York: Arnold, Oxford University Press.

Hall, S. (1999), 'Whose heritage? Un-settling "the heritage", re-imagining the Postnation', Third Text, 13 (49), 3-13. https://doi.org/10.1080/09528829908576818

Harrison, R. (2012), Heritage: Critical Approaches, London and New York: Routledge.

Hart, S. (2011), 'Heritage, neighborhoods and cosmopolitan sensibilities: Poly-communal archaeology in Deerfield, Massachusetts', Present Pasts, 3 (1), 26-34, doi: 10.5334/pp.42.

Kisić, V. (2017), Governing Heritage Dissonance: Promises and Realities of Selected Cultural Policies, Belgrade: European Cultural Foundation (ECF). 
Meskell, L. (2015), 'Introduction: Globalizing heritage', in L. Meskell (ed.), Global Heritage: A Reader, Chichester, UK: John Wiley and Sons.

Nadin, V., W. van der Toorn Vrijthoff, A.A. Kermani et al. (2018), Cultural Heritage: A Challenge for Europe. The Impact of Urban Planning and Governance Reform on the Historic Built Environment and Intangible Cultural Heritage (PICH), Delft: TU Delft, retrieved from https://planningandheritage.files.wordpress.com/2018/04/pich -final-report-060418.pdf

Pendlebury, J. (2002), 'Conservation and regeneration: Complementary or conflicting processes? The case of Grainger Town, Newcastle upon Tyne', Planning Practice and Research, 17 (2), 145-58.

Pendlebury, J., M. Scott, L. Veldpaus, W. van der Toorn Vrijthoff and D. Redmond (2019), 'After the crash: The conservation-planning assemblage in an era of austerity', European Planning Studies, doi: 10.1080/09654313.2019.1629395

Rex, B. (2018), Local Authority Museums after the Cuts: A Study of Other-than-Public Forms of Management (PhD Thesis), Newcastle University, School of Arts and Cultures: Newcastle upon Tyne, UK.

Sinclair-Chapman, V. (2018), '(De)Constructing symbols: Charlottesville, the confederate flag, and a case for disrupting symbolic meaning', Politics, Groups, and Identities, 6 (2), 316-23.

Smith, L. (2006), Uses of Heritage, Abingdon, UK and New York: Taylor and Francis.

Smith, L., M. Wetherell and G. Campbell (2018), Emotion, Affective Practices, and the Past in the Present, London and New York: Routledge.

Tolia-Kelly, D.P., E. Waterton and S. Watson (eds) (2017), Heritage, Affect and Emotion: Politics, Practices and Infrastructures, London and New York: Routledge, Taylor and Francis Group.

Veldpaus, L. and J. Pendlebury (2019), 'Heritage as a vehicle for development: The case of Bigg Market, Newcastle upon Tyne', Planning Practice and Research, 1-15, doi: 10.1080/02697459.2019.1637168.

Wacogne, R. (2018), 'Venezia (in-)sostenibile. Usi e pratiche del patrimonio urbano', in G. Fini, V. Saiu and C. Trillo (eds), UPhD Green: Il dottorato come luogo esplorativo della ricerca sulla sostenibilità. Servizio monografico: Planum Magazine, 37 (2), 127-35. 
Loes Veldpaus and Remi Wacogne - 9781788974639 Downloaded from PubFactory at 04/26/2023 10:28:34AM via free access 